\title{
Đô thị hóa và tăng trưởng kinh tế tại vùng kinh tế trọng điểm phía Nam
}

\section{Urbanization and growth in Southern key economic region}

\author{
Trần Mạnh Hùng ${ }^{1}$, Lê Thanh Tùng ${ }^{1 *}$, Lê Tuấn Anh $^{2}$ \\ ${ }^{1}$ Trường Đại học Mở Thành phố Hồ Chí Minh, Việt Nam \\ ${ }^{2}$ Trường Đại học Nguyễn Tất Thành, Việt Nam \\ *Tác giả liên hệ, Email: tung.lt@ou.edu.vn
}

\section{THÔNG TIN}

DOI: 10.46223/HCMCOUJS.

proc.vi.16.1.1864.2021

Ngày nhận: 7/3/2021

Ngày nhận lại: 31/3/2021

Duyệt đăng: 10/4/2021

\section{Tù khóa:}

đô thị hóa, tăng trưởng kinh tế, phát triển bền vững, vùng kinh tế trọng điểm phía Nam

\section{Keywords:}

urbanization, economic growth, sustainable development,

Southern Key Economic Zone

\section{TÓM TẮT}

Quá trình phát triển kinh tế đã dẫn đến đô thị hóa nhanh chóng tại các tỉnh thành thuộc vùng kinh tế trọng điểm phía Nam. Tuy nhiên, đô thị hóa tràn lan có thể tạo ra bất ổn và kéo theo xu hướng tăng trưởng kinh tế không bền vững. Bài báo thực hiện một số mục tiêu sau: (1) Giới thiệu cơ sở lý thuyết về phát triển đô thị hóa gắn với thúc đẩy tăng trưởng kinh tế, (2) Phân tích thực trạng đô thị hóa trong bối cảnh thực hiện định hướng thúc đẩy kinh tế tăng trưởng mạnh mẽ hơn tại các tỉnh thành thuộc vùng kinh tế trọng điểm phía Nam, và (3) Đề xuất một số hàm ý chính sách để thúc đẩy quá trình đô thị hóa gắn với thúc đẩy tăng trưởng kinh tế tại các tỉnh thành thuộc vùng kinh tế trọng điểm phía Nam trong thời gian tới.

ABSTRACT
The economic development process has led to rapid
urbanization in the Southern key economic region in Vietnam.
However, unplanned urbanization can create instability and lead
to unsustainable economic growth. The paper has some research
objectives: (1) Introducing the theoretical framework of
urbanization development associated with promoting economic
growth, (2) Analyzing the current state of urbanization in the
current context to promote economic growth in the Southern key
economic region, (3) Proposing policy implications to support
urbanization in association with promoting economic growth in
the provinces in this key economic region in the coming time.

\section{Giới thiệu}

Lịch sử quá trình phát triển của các quốc gia trên thế giới đều cho thấy hiện tượng đô thị hóa (urbanization) luôn tuân theo một quy luật đó là quá trình công nghiệp hóa, hiện đại hóa sẽ khởi động, thúc đẩy và làm "bùng nổ” quá trình đô thị hóa (Liddle \& Messinis, 2015; Williamson, 1987; Williamson, 1990). Trên thực tế các tổ hợp sản xuất, các nhà máy, các doanh nghiệp thường đặt trụ sở tại các khu đô thị hoặc vùng ven khu đô thị do nhiều yếu tố, ví dụ như: cơ sở hạ tầng hoàn thiện, dân số qua đào tạo có tỷ lệ cao hơn tại nông thôn, quy mô dân số (lực lượng lao động) đông đảo và hệ thống giao thông thuận tiện hơn. Quá trình đô thị hóa mang lại nhiều điểm tích cực như giúp chuyển dịch khu vực kinh tế từ sản xuất công nghiệp, nông nghiệp sang cung cấp các 
loại hình dịch vụ, giúp chuyển dịch cơ cấu kinh tế cũng như tạo "bộ mặt" cho quốc gia (Henderson, 2010). Quá trình đô thị hóa cũng đồng thời giúp nâng cao chất lượng cuộc sống người dân thông qua việc gia tăng nguồn cung và nâng cao chất lượng hệ thống nhà ở. Tuy nhiên quá trình đô thị hóa cũng có nhiều mặt trái dẫn đến quá trình phát triển không bền vững, ví dụ như đô thị hóa tự phát kéo theo phá vỡ cảnh quan quy hoạch hoặc đô thị hóa tràn lan sẽ dẫn đến quá tải cơ sở hạ tầng hoặc đô thị hóa không được quản lý chặt chẽ sẽ làm "bùng nổ” hiện tượng đầu cơ, thao túng thị trường bất động sản làm xuất hiện tình trạng "bong bóng” giá nhà ở và dẫn đến một lượng lớn hộ gia đình không đủ khả năng có được nhà ở ổn định.

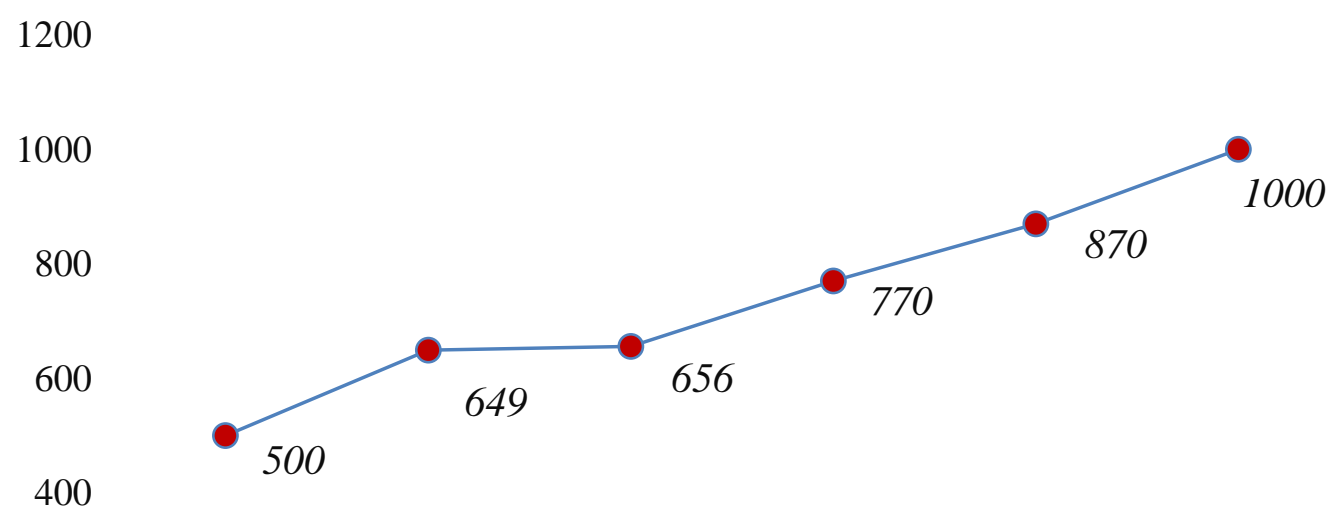

0

$1990 \quad 2000 \quad 2003 \quad 2013 \quad 2015 \quad 2025 f$

Hình 1. Số lượng đô thị tại Việt Nam 1990-2015 và dự báo 2025

Nguồn: Tổng cục thống kê (2021)

Vùng Kinh Tế Trọng Điểm Phía Nam (VKTTĐPN) bao gồm các tỉnh thành là Thành phố Hồ Chí Minh, Bà Rịa - Vũng Tàu, Đồng Nai, Bình Dương, Bình Phước, Tây Ninh, Long An và Tiền Giang. VKTTĐPN có vai trò rất quan trọng đối với sự phát triển của Việt Nam khi các tỉnh thành trong khu vực này đóng góp đến $42 \%$ GDP và chiếm $43 \%$ thu ngân sách quốc gia trong năm 2019 (Tổng cục thống kê, 2020). Diện tích tự nhiên toàn vùng trên 30 ngàn $\mathrm{km}^{2}$, chiếm $9,2 \%$ diện tích cả nước. Trong đó, TpHCM vừa là “đầu tàu” kinh tế của quốc gia nhưng cũng đồng thời đóng vai trò "hạt nhân" và là trung tâm phát triển của VKTTĐPN. Bài viết của chúng tôi sẽ cung cấp thêm minh chứng về mối quan hệ giữa đô thị hóa và tăng trưởng kinh tế, tiếp theo, nhóm nghiên cứu sẽ phân tích thực trạng đô thị hóa tại VKTTĐPN tương ứng với định hướng thúc đẩy tăng trưởng kinh tế. Cuối cùng, bài viết trình bày một số hàm ý chính sách nhằm gắn kết chặt giữa đô thị hóa với thúc đẩy tăng trưởng kinh tế tại VKTTĐPN trong giai đoạn tới.

\section{Cơ sở lý thuyết về mối quan hệ giữa đô thị hóa và tăng trưởng kinh tế}

Các lý luận về đô thị, đô thị hóa và những vấn đề liên quan được nhiều nhà khoa học và tổ chức quốc tế quan tâm nghiên cứu. Mặc dù khá thống nhất nhau về các dấu hiệu đặc trưng của một điểm quần cư đô thị nhưng các chỉ tiêu và ngưỡng giá trị của chỉ tiêu để xác định một điểm quần cư đô thị lại rất khác nhau giữa các nhà nghiên cứu, các quốc gia. Vì thế, khái niệm đô thị chưa có sự thống nhất hoàn toàn. Nhìn chung, trên thế giới có khoảng 30 định nghĩa về đô thị đang được sử dụng và chúng rất khác nhau. Dựa trên tư liệu lịch sử của quá trình đô thị hóa ở Châu Âu và Bắc Mỹ, các nhà đô thị học đã tiến hành phân kỳ quá trình đô thị hóa theo các giai đoạn: giai đoạn 
sơ khai khi tỷ lệ dân số đô thị thấp và tốc độ gia tăng chậm chạp; tiếp theo đó là giai đoạn tăng tốc và kết thúc bằng giai đoạn chín muồi với tỷ lệ dân số đô thị cao nhưng tăng rất chậm hoặc không tăng thậm chí có xu hướng giảm nhẹ". Tính giai đoạn này được biểu diễn bằng đường cong đô thị hóa. Tuy nhiên, cũng có nhiều nghiên cứu chia quá trình đô thị hóa thành 2,3 hoặc 4 giai đoạn căn cứ vào tỷ lệ dân số đô thị. Đô thị hóa là một quá trình đa diện về địa lý - lịch sử, dân số, kinh tế xã hội và văn hóa, vì vậy tùy theo hoàn cảnh nghiên cứu, sự phù hợp của các chỉ tiêu dân số, kinh tế - xã hội, các tác giả khác nhau đã lựa chọn các chỉ tiêu định tính và định lượng để đo lường trình độ và tốc độ đô thị hóa.

Nghiên cứu của Lucas (2004) và Lucas (2007), xem xét rõ ràng việc đô thị hóa ảnh hưởng đến quá trình tăng trưởng như thế nào (chủ yếu thông qua việc nâng cao các ý tưởng và kiến thức được cho là do sự kết tụ ở các thành phố. Theo một cách xử lý lịch sử hơn, Landes (1969), đặt đô thị hóa như một thành phần thiết yếu của quá trình công nghiệp hóa và là trọng tâm của một quá trình lớn hơn, phức tạp hơn thường được gọi là hiện đại hóa. Hiện đại hóa bao gồm cả những vấn đề liên quan đến phát triển như đô thị hóa, quá trình chuyển đổi trong quản lý đô thị và việc thiết lập cơ chế quản lý hiện đại của chính quyền. Mặt khác, đô thị hóa là một lĩnh vực tương đối ít được nghiên cứu về kinh tế và chính sách phát triển khi không gian đô thị gia tăng được thể hiện rõ nét nhất qua vai trò của đô thị hóa và của các thành phố lớn trong quá trình phát triển bất chấp sự suy thoái kinh tế có liên quan đến các thành phố lớn của đất nước đang phát triển. Thậm chí còn có nhiều nền kinh tế mạnh mẽ hơn về quy mô khiến việc đặt trụ sở tại các thành phố này trở nên đáng giá.

Lewis (1977) bày tỏ lo ngại về chi phí đô thị hóa nhưng coi đó là điều không thể tránh khỏi khi cho rằng các quốc gia có thể phát triển công nghiệp xung quanh vùng nông thôn thay vì tập trung ở các thị trấn, nhưng điều này là khó khăn trong việc thực hiện. Người ta có thể làm việc chăm chỉ để thành lập các ngành công nghiệp nông thôn, điều này nhất định bị hạn chế. Ý thức về tính tất yếu của Lewis (1977) được đúc kết theo kinh nghiệm: "rất ít quốc gia đạt mức thu nhập 10000 USD trên đầu người trước khi đạt mức đô thị hóa khoảng 60\%". Tác giả Collier (2006) đưa ra một số lời giải thích cho hiệu quả tăng trưởng kém của một loạt các quốc gia châu Phi: "Các yếu tố địa lý - bao gồm khí hậu, thổ nhưỡng và sự thất bại trong việc đạt được một cuộc cách mạng xanh - và ranh giới quốc gia đóng những vai trò rất quan trọng”. Barrios, Luisito, và Strobl (2006) đã phân tích dữ liệu chuỗi thời gian xuyên quốc gia để kiểm tra các giả thuyết về yếu tố thúc đẩy quá trình đô thị hóa. Phân tích quốc gia toàn cầu của họ cho thấy xu hướng giảm lượng mưa có tác động tích cực và đáng kể đến quá trình đô thị hóa, mặc dù tác động này chỉ xuất hiện ở châu Phi. Do đó, các quốc gia đang phát triển chậm, đô thị hóa nhanh ở Châu Phi có thể đang trải qua quá trình đô thị hóa "thúc đẩy" chứ không phải là "kéo", do căng thẳng nông nghiệp.

Các tác giả Rosenthal và William (2004) đã cung cấp một góc nhìn toàn diện trong lĩnh vực học thuật liên quan đến đô thị hóa. Hầu hết các công trình nghiên cứu trong lĩnh vực này tập trung tại các quốc gia phát triển và chỉ có một số ít nghiên cứu thực hiện tại các nước đang phát triển (Greenstone, Hornbeck, \& Moretti, 2007). Một số kết quả nghiên cứu đã cho thấy rằng nếu quy mô đô thị hóa tăng thì sẽ làm tăng năng suất của các ngành công nghiệp. Tác giả Greenstone và cộng sự (2007), tiến hành kiểm định sự khác biệt về những thay đổi trong chi tiêu hộ gia đình tại Bangladesh. Trong nghiên cứu này thì mức độ đô thị hóa được sử dụng để nghiên cứu vấn đề bất bình đẳng trong khu vực hộ gia đình.

Tổ chức Liên Hiệp Quốc (United Nations-UN) sử dụng chỉ tiêu tỷ lệ dân số đô thị so với tổng dân số quốc gia để đánh giá tốc độ đô thị hóa và sự thay đổi trung bình năm của tỷ lệ dân số đô thị để đánh giá tốc độ đô thị hóa. Trong "Dân số, đô thị hóa và chất lượng cuộc sống" do Cơ quan định cư con người của UN lưu hành trong Hội nghị quốc tế về dân số và phát triển tại Nairobi 
năm 1994 có đề cập đến những tác động của quá trình đô thị hóa đến các khía cạnh nhân khẩu học, xã hội và kinh tế. Theo tài liệu này, quá trình đô thị hóa có tác động tích cực làm thay đổi xã hội và thúc đẩy quá trình hiện đại hóa: giảm mức sinh, mức tử vong và qui mô hộ gia đình; đồng thời làm tăng mức thu nhập của cá nhân và hộ gia đình và thúc đẩy sự phát triển kinh tế chung của cả khu vực nông thôn và thành thị. Sự gia tăng các phương tiện truyền thông tập trung ở thành phố cũng là những tác nhân góp phần khếch tán sự đổi mới và chuyển đổi kinh tế - xã hội.

Theo các tác giả Satterthwaite (2007) cho rằng "những lợi thế của tích tụ đất đai cũng khác nhau giữa các lĩnh vực của nền kinh tế”. Kết quả nghiên cứu rất có ý nghĩa đối với mối quan hệ giữa đô thị hóa và tăng trưởng. Thành công về kinh tế nói chung liên quan đến sự chuyển dịch dần dần ra khỏi nông nghiệp (ngay cả khi năng suất nông nghiệp tăng lên) và quá trình chuyển hướng của các nguồn lực sang các khu vực công nghiệp và dịch vụ. Nông nghiệp thâm dụng đất hơn và thu được lợi nhuận từ việc phân tán khắp nông thôn, trong khi các ngành công nghiệp và dịch vụ được hưởng lợi từ việc tập trung. Điều này giúp giải thích tại sao đô thị hóa có liên quan khá chặt chẽ đến tỷ trọng GDP của một quốc gia trong ngành công nghiệp và dịch vụ. Mặc dù vậy, không thể khẳng định chắc chắn là tốc độ đô thị hóa nhanh hơn sẽ dẫn đến tăng trưởng kinh tế nhanh hơn. Thay vào đó, nó gợi ý một loại mối quan hệ cân bằng hoặc phụ thuộc lẫn nhau, trong đó đô thị hóa giúp duy trì tăng trưởng nhưng có thể phản tác dụng nếu nó vượt quá cơ cấu kinh tế và gây khó khăn cho việc hấp thụ lực lượng lao động dư thừa ở thành thị (Loughran \& Schultz, 2005).

Theo Dorosh và James (2012) thì đô thị hóa đồng nghĩa với việc giảm tỷ lệ dân số cư trú tại khu vực nông thôn. Tại những khu vực mà có mật độ dân số quá đông ở nông thôn là một vấn đề và đô thị hóa có thể hỗ trợ để nâng cao năng suất thông qua việc phân bố lại cư dân quốc gia. Đô thị hóa cũng có thể làm giảm khoảng cách kinh tế giữa nông thôn và thành thị thông qua việc cải thiện cơ sở hạ tầng kết nối. Tuy nhiên, không phải tất cả các hình thức đô thị hóa đều có tác động như nhau đến năng suất và thu nhập ở nông thôn. Phần lớn sẽ phụ thuộc vào số lượng thành phố đang trong quá trình mở rộng, cho dù đô thị hóa là quá trình tập trung về mặt không gian trên các khu vực địa lý khác nhau và loại cơ sở hạ tầng sẽ được đầu tư.

Một số kết quả nghiên cứu lại cho thấy rằng có một hiện tượng phổ biến là các quốc gia có tỷ lệ đô thị hóa cao thì sẽ có xu hướng thịnh vượng hơn (Burgess \& Venables, 2003). Tác giả Henderson (2010), đã phát hiện mối tương quan chặt chẽ giữa tỷ lệ đô thị hóa và tổng thu nhập quốc dân bình quân đầu người tại một số quốc gia. Tác giả cho rằng: "mối tương quan sẽ thậm chí còn mạnh mẽ hơn nếu có giảm thiểu được sự khác biệt hơn trong cách thức xác định "đô thị" tại các quốc gia". Tuy nhiên, phạm vi quan sát xung quanh đường xu hướng luôn rất rộng, cho thấy rằng một số yếu tố vĩ mô khác cũng có liên quan. Bên cạnh đó, việc phát hiện ra một sự liên kết về mặt thống thống kê tất nhiên không phải là bằng chứng về mối liên hệ nhân quả. Đô thị hóa có thể là hệ quả của quá trình phát triển kinh tế, và có thể có các mức độ đô thị hóa khác nhau phù hợp với các nền kinh tế khác nhau.

Một nghiên cứu thực hiện bởi Liddle (2013), đã tìm thấy mối liên hệ chặt chẽ giữa đô thị hóa và tăng trưởng kinh tế. Tuy nhiên, nghiên cứu cũng cho rằng đô thị hóa là động lực thúc đẩy tăng trưởng kinh tế và tác động của nó khác nhau giữa các khu vực (quốc gia), tùy thuộc vào mức thu nhập và sự phát triển của họ. Trong nghiên cứu gần đây các tác giả Liddle và Messinis (2015), đã xác định thêm một số vấn đề trong mối quan hệ giữa đô thị hóa và tăng trưởng kinh tế và khẳng định cho thấy mối tương quan này đang gia tăng ở tấc cả các nước thu nhập cao và thu nhập thấp.

\section{Thực trạng đô thị hóa tại vùng kinh tế trọng điểm phía nam}

\section{1. Đô thị hóa quan hệ chặt chẻ với quá trình công nghiệp hóa}

Tuy nhiên tại Việt Nam nói chung và khu vực Đông Nam Bộ nói riêng thì đô thị hóa kéo 
theo công nghiệp hóa và nguyên nhân chính của hiện tượng ấy là do sức ép về nhà ở. Sự phát triển "ngược quy luật" khiến hệ thống đô thị ở Việt Nam bộc lộ những yếu kém (có thể được gọi là "căn bệnh đô thị") về: kiến trúc, giao thông, nước thải sinh hoạt, di dân tự do và các vấn đề an sinh xã hội khác. Tại các tỉnh thành thuộc Vùng Kinh Tế Trọng Điểm Phía Nam (VKTTĐPN), có thể nhận thấy một sự đứt gãy, phá vỡ cảnh quan sống của không gian kiến trúc nông thôn truyền thống. Tình trạng bê tông hóa nhà ở nông thôn, đường liên xã, xóm, ven đê, ven đường cao tốc đã cho thấy những hạn chế của việc quy hoạch phát triển đô thị và khu vực nông thôn trong quá trình công nghiệp hóa - hiện đại hóa tại VKTTĐPN hiện nay.

VKTTĐPN là nơi tập trung số lượng các khu công nghiệp lớn và thu hút nhiều dự án đầu tư nước ngoài lớn nhất của cả nước. Tại VKTTĐPN có đa dạng các loại hình công nghiệp như Khu công nghệ cao, 2 khu chế xuất Tân Thuận và Linh Trung, Công viên phần mềm Quang Trung và hàng chục khu công nghiệp $(\mathrm{KCN})$ thu hút khác như: Biên Hòa, Nhơn Trạch, Loteco, Amata (Đồng Nai), Sóng Thần, Việt Nam - Singapore, Việt Hương, Nam Tân Uyên, Mỹ Phước, Đồng An (Bình Dương), Tân Tạo, Vĩnh Lộc, Tân Bình (TpHCM)... Ngoài ra còn có một số khu công nghiệp tập trung ở Long An (Bến Lức, Cần Giuộc, Cần Đước, Thủ Thừa, Đức Hòa và Tân An), Tiền Giang như Khu Công nghiệp Mỹ Tho (79.14 ha), KCN Tân Hương (197 ha), KCN Long Giang (600 ha), KCN Dịch vụ Dâu Khí (1000 ha), cụm Trung An (17 ha), cụm Tân Mỹ Chánh $(23,57$ ha) và đang chuẩn bị xây thêm KCN Nam Tân Phước (dự kiến là 1000 ha). Các ngành công nghiệp quan trọng của Vùng gồm: Dầu khí, dày da, dệt may, điện tử, cơ khí, hóa chất, phân bón, cán thép...

Trong tương lai không xa, với tốc độ đô thị hóa nhanh chóng, đây sẽ là vùng đô thị lớn (metropolitan area) có quy mô lớn trong khu vực Đông Nam Á và cả khu vực Châu Á-Thái Bình Dương. Hiện tại ở đây đang triển khai một số dự án khu đô thị lớn như: khu đô thị công nghiệp tổng hợp Bình Dương quy mô 4000 ha, khu đô thị Đông Bắc Củ Chi và Long An 4000 ha, khu đô thị Phú Mỹ Hưng 600 ha và là khu đô thị mới Thủ Thiêm 700 ha. Trong tương lai xây dựng thêm một số thành phố mới như: Nhơn Trạch, Bình Dương, Long Thành, Phú Mỹ, Hậu Nghĩa và Cần Giuộc. Đô thị hóa và công nghiệp hóa luôn có mối quan hệ phụ thuộc, bổ sung hỗ trợ lẫn nhau. Bằng chứng rõ nét cho sự kết hợp này thể hiện qua số lượng các khu công nghiệp tại Việt Nam tăng nhanh cùng với quá trình đô thị hóa. Cụ thể, số liệu thống kê sơ bộ vào năm 2020 thì Việt Nam có 305 khu công nghiệp, trong đó cụm các khu công nghiệp tại VKTTĐPN cụ thể như bảng sau:

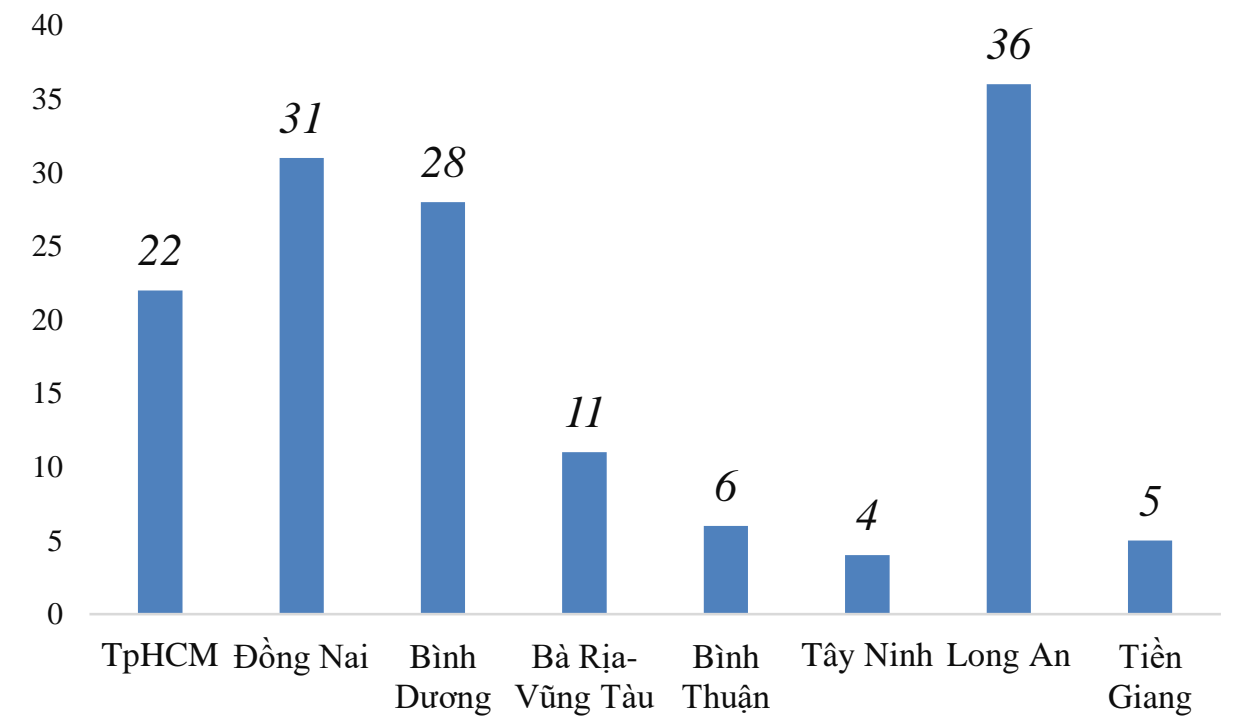


Hình 2. Số lượng khu công nghiệp các tỉnh thuộc VKTTĐPN, 2020

Nguồn: Tổng cục thống kê (2021)

Như vậy, số lượng khu công nghiệp là 143 thì VKTTĐPN đã chiếm gần 50\% tổng số các khu công nghiệp của cả nước, trong đó có những địa phương đã trở thành vùng công nghiệp, như: Long An (36), Đồng Nai (31), Bình Dương (28), Tp. Hồ Chí Minh (22). Bên cạnh đó, hình 2 đã cho thấy sự phát triển không đồng đều về số lượng khu công nghiệp của các tỉnh thành thuộc VKTTĐPN. Thực tiễn cũng cho thấy các địa phương có khu công nghiệp nhiều cũng đồng thời có tỷ lệ đô thị hóa cao và tăng trưởng kinh tế mạnh mẽ.

\section{2. Đô thị hóa diễn ra không đồng đều, đa số là đô thị loại vù̀a và nhỏ}

Trong thời gian qua, cùng với quá trình công nghiệp hóa, hiện đại hóa đất nước, nhiều khu công nghiệp lớn đã được xây dựng ở các thành phố như Tp.HCM, Đồng Nai, Bình Dương... quá trình đô thị hóa cũng diễn ra hết sức nhanh chóng. Sự phát triển của các khu công nghiệp, khu đô thị và sự năng động của các thành phần kinh tế đã tạo ra được nhiều công ăn việc làm, thu hút một số lượng lớn lao động từ khu vực nông thôn di cư ra thành thị để tìm việc làm. Trên thực tế, đô thị hóa tại Việt Nam nói chung và các tỉnh thành VKTTĐPN diễn ra không đồng đều và có phần mang tính “tự phát”. Các đô thị loại nhỏ là chủ yếu và thuộc các thành phố, thị xã thuộc tỉnh, hoặc là thị trấn thuộc huyện. Theo số liệu dự báo của Ngân hàng Thế giới, với mức độ đô thị hóa như hiện nay của Việt Nam, riêng tỷ lệ đô thị loại V có thể lên tới $90 \%$ năm 2020 . Quy luật phổ biến trong quá trình phát triển xã hội là sự phát triển không đồng đều giữa các quốc gia, trong mỗi quốc gia cũng có sự phát triển không đồng đều giữa các vùng, các địa phương. Quy luật này cũng đúng với quá trình đô thị hóa ở Việt Nam, với sự phát triển không đồng đều giữa các vùng kinh tế - xã hội. Năm 2019 tỷ lệ đô thị hóa của cả nước là 34,4\%, vùng Đông Nam Bộ có tỷ lệ đô thị hóa cao gấp 2 lần so với mức độ đô thị hóa của cả nước. Trên thực tế, khu vực Đông Nam Bộ có tỷ lệ dân số thành thị cao nhất cả nước $(62,8 \%)$. Các tỉnh có tỷ lệ dân số thành thị cao nhất gồm Bình Dương và $\mathrm{TpHCM}$ (tương ứng là $79,9 \%$ và $79,2 \%$ ).

Theo số liệu từ Trung tâm Thông tin và Dự báo kinh tế xã hội quốc gia (Bộ Kế hoạch và Đầu tư, 2019) thì nhìn một cách bao quát, có thể thấy, hệ thống đô thị Việt Nam đã có bước phát triển nhanh chóng, tỷ lệ đô thị hóa tăng nhanh từ 19,6\% với 629 đô thị năm 2009 lên khoảng 36,6\% với 802 đô thị năm 2016. Tính đến hết năm 2018, Việt Nam đã có 819 đô thị (tăng 6 đô thị so với năm 2017); tỷ lệ đô thị hóa cả nước đạt khoảng 38,4\% (tăng 0,9\% so với năm 2017). Tăng trưởng đô thị nhanh nhất ở hai thành phố lớn là Hà Nội và TpHCM, sau đó là Hải Phòng, Đà Nẵng, và Cần Thơ. Tính đến tháng 4/2019, số đô thị của cả nước đã tăng lên con số 830, bao gồm 2 đô thị đặc biệt là Hà Nội và TpHCM, 19 đô thị loại I, 29 đô thị loại II, 45 đô thị loại III, 80 đô thị loại IV và 655 đô thị loại $\mathrm{V}$.

Bên cạnh đó, dân cư trong các đô thị thuộc các tỉnh thành VKTTĐPN cũng có sự phân bố không phù hợp, chủ yếu tập trung ở các đô thị lớn như TP.Hồ Chí Minh, Đồng Nai và Bình Dương. Tại các tỉnh khác mức đô thị hóa vẫn còn thấp và các thành phố thuộc tỉnh khá nhỏ. Chính vì sự phát triển đô thị không đồng đều này và mật độ dân số đông tại một vài thành phố lớn, nên các thành phố lớn (ví dụ, Tp.HCM) đang phải chịu đựng sự quá tải về cơ sở hạ tầng kỹ thuật do các dòng di cư từ các địa phương vào đô thị lớn, gây nguy cơ phát triển đô thị thiếu bền vững và làm giảm động lực tăng trưởng kinh tế.

\section{3. Đô thị hóa thúc đẩy di cu và mật độ dân số cao ở các đô thị lớn}

Bên cạnh quy mô đô thị vừa và nhỏ, tỷ lệ dân cư đô thị tại Việt Nam cũng không cao. Mặc dù tỷ lệ dân cư đô thị bình quân cả nước có tăng lên, từ 27,44\% năm 2007 đến 34.4\% năm 2019 
nhưng sự tăng trưởng dân số đô thị chủ yếu diễn ra ở các khu vực đô thị lớn với 400.000 dân trở lên. Dân số tại các đô thị lớn gồm Hà Nội và Tp.HCM đã chiếm khoảng một phần ba tổng dân số đô thị toàn quốc. Tỷ lệ đô thị hóa của Việt Nam ước tính đến cuối năm 2019 đạt khoảng 34,4\% và dự báo sẽ còn gia tăng nhanh chóng.

Di cư hay di dân là một thuật ngữ mô tả quá trình di chuyển dân số hoặc quá trình con người rời bỏ hoặc hội nhập, hoặc thiết lập nơi cư trú mới vào một đơn vị hành chính - địa lý trong một thời gian nhất định. Di dân có thể liên quan đến sự di chuyển của một cá nhân, một gia đình, thậm chí cả một cộng đồng (Lucas, 2004). Một điều có thể nhận thấy là không phải mọi sự di chuyển của con người đều được coi là di dân. Từ các nghiên cứu, chúng tôi đồng tình với quan điểm cho rằng: Di dân là sự di chuyển của người dân theo lãnh thổ với những giới hạn về thời gian và không gian nhất định, kèm theo sự thay đổi nơi cư trú. Theo cách tiếp cận trên đây, di dân có những đặc điểm là: Một là, con người di chuyển khỏi một nơi nào đó đến một nơi khác, với một khoảng cách nhất định. Nơi đi (nơi xuất cư) và nơi đến (nơi nhập cư) phải được xác định, có thể là vùng lãnh thổ hoặc một đơn vị hành chính. Khoảng cách giữa hai điểm là độ dài di dân. Hai là, con người khi di dân bao giờ cũng với những mục đích nhất định, họ đến một nơi nào đó và ở lại đó trong một thời gian nhất định. Ba là, nơi đi (xuất phát) là nơi ở thường xuyên, được quy định theo hình thức đăng ký hộ khẩu hoặc đăng ký dân sự xác định của cấp quản lý hành chính có thẩm quyền và nơi đến là nơi ở mới. Tính chất cư trú là điều kiện cần để xác định di dân. Bốn là, khoảng thời gian ở lại nơi mới trong bao lâu là đặc điểm quan trọng xác định sự di chuyển đó có phải là di dân hay không. Đông Nam Bộ là điểm đến thu hút nhất đối với người di cư, có đến 1,3 triệu người nhập cư đến vùng Đông Nam Bộ, chiếm hơn hai phần ba tổng số người di cư giữa các vùng trên cả nước. Phần lớn người nhập cư đến các tỉnh thành VKTTĐPN là người của vùng Đồng bằng sông Cửu Long (710 nghìn người, chiếm 53,2\%).

Theo Tổng điều tra dân số năm 2019, dân số thành thị là 33,1 triệu người, chiếm 34,4\% tổng dân số cả nước; dân số nông thôn là 63,08 triệu người, chiếm $65,6 \%$. Tỷ lệ tăng dân số bình quân năm khu vực thành thị giai đoạn 2009 - 2019 là 2,64\%/năm, gấp hơn hai lần tỷ lệ tăng dân số bình quân năm của cả nước và gấp sáu lần so với tỷ lệ tăng dân số bình quân năm khu vực nông thôn cùng giai đoạn. Toàn quốc có 12 tỉnh có tỷ suất di cư thuần dương, nghĩa là người nhập cư nhiều hơn người xuất cư. Trong đó, tỉnh Bình Dương có tỷ suất di cư thuần dương cao nhất (200,4\%) với hơn 489 nghìn người nhập cư nhưng chỉ có khoảng 38 nghìn người xuất cư khỏi tỉnh này trong 5 năm trước. Như vậy, cứ 5 người từ 5 tuổi trở lên ở tỉnh Bình Dương thì có 1 người đến từ tỉnh khác. Tìm việc/bắt đầu công việc mới hoặc theo gia đình/chuyển nhà là những lý do di cư chủ yếu. Có $43 \%$ người di cư đang phải sống trong các căn nhà thuê mượn, gấp gần tám lần tỷ lệ này của người không di cư. Các địa phương có nhiều khu công nghiệp thu hút đông lao động phổ thông là những nơi có tỷ lệ người di cư phải thuê/mượn nhà cao nhất, như: Bình Dương, Đồng Nai, Cần Thơ. Trong đó, Bình Dương là tỉnh có tỷ lệ người di cư phải thuê/mượn nhà cao nhất cả nước $(74,5 \%)$. Bên cạnh đó, một số địa phương khác cũng có tỷ lệ này khá cao (từ 40-50\%) bao gồm: Tây Ninh, Bà Rịa - Vũng Tàu, Tp.HCM và Long An. Tuy nhiên, các số liệu nêu trên chưa bao gồm nhiều loại hình di dân như ngắn hạn, mùa vụ, những người tạm trú hay những sự di chuyển diễn ra hơn 5 năm trước khi tiến hành cuộc điều tra. Vì thế nhiều chuyên gia cho rằng, số lượng người di dân thực tế tới VKTTĐPN trong thời gian qua còn lớn hơn nhiều so với các con số nêu trên.

Vấn đề nhà ở cho những người di cư: vấn đề này đã được nhiều nhà nghiên cứu về di dân đề cập đến và đều thừa nhận rằng, đây là một vấn đề nan giải, một áp lực lớn đối với các chính quyền cấp tỉnh tại VKTTĐPN. Đại đa số những người di cư vào thành phố không thể mua được nhà riêng, họ phải ở thuê trong những khu nhà trọ được xây dựng tạm bợ, không đủ các điều kiện sinh hoạt tối thiểu... Nhiều người cùng thuê một căn phòng chật hẹp, không đủ tiện nghi, môi 
trường ô nhiễm làm ảnh hưởng đến sức khỏe của bản thân họ và cả cư dân xung quanh. Việc giải quyết nhà ở cho cư dân sinh sống chính thức ở thành phố chưa bao giờ là vấn đề dễ dàng đối với chính quyền, nhất là các thành phố lớn; nay lại thêm làn sóng đông đảo người di cư ồ ạt đổ về khiến cho vấn đề vốn đã khó khăn lại trở nên khó khăn gấp bội. Mặc dù các cơ quan chức năng đã có những chính sách để tháo gỡ, như việc đầu tư xây dựng những khu nhà dành riêng cho người có thu nhập thấp, nhưng người di cư không dễ dàng tiếp cận được, do điều kiện tài chính của họ còn hạn hẹp. Cũng do khó khăn trong nơi cư trú nên nhiều người di cư phải sống ở những nơi công cộng, những nơi mà trước đây được xã hội gọi là các "xóm liều". Những đối tượng này thường không khai báo tạm trú, tạm vắng với công an khu vực nên việc quản lý họ gặp nhiều khó khăn. Trong số những người di cư ra thành phố có cả những phần tử có tiền án, tiền sự trà trộn vào các khu nhà trọ, một số thanh niên sa ngã vào các tệ nạn xã hội khiến cho tình hình an ninh, trật tự xã hội ở một số địa phương tại VKTTĐPN nảy sinh nhiều vấn đề phức tạp. Ngoài ra, sự phát triển các cơ sở hạ tầng như trường học, bệnh viện, giao thông đô thị cũng không theo kịp với sự gia tăng số lượng người di cư đã làm nảy sinh nhiều vấn đề xã hội nan giải.

Những khó khăn trong công việc: phần lớn những người di cư tự do từ nông thôn ra thành thị có trình độ tay nghề thấp, chưa qua đào tạo, chưa được trang bị những hiểu biết cần thiết về điều kiện lao động công nghiệp, về môi trường sinh sống ở đô thị nên họ thường gặp khó khăn trong tìm kiếm việc làm, không biết bảo vệ các quyền và quyền lợi của người lao động do luật pháp quy định. Đa số người lao động tự do, làm việc trong khu vực kinh tế phi chính thức, chấp nhận làm việc không có hợp đồng lao động, không có bảo hiểm, mà chỉ thỏa thuận miệng về tiền công, việc làm với chủ sử dụng lao động. Vì vậy, thời gian lao động của họ thường bị kéo dài hơn thời gian do luật định; chế độ nghỉ ngơi không bảo đảm; khi ốm đau không được chăm sóc sức khỏe. Nguy cơ bị bóc lột, lạm dụng: do trình độ văn hóa thấp, thiếu hiểu biết về pháp luật, nên họ dễ bị lạm dụng, bị bóc lột, đặc biệt là chị em phụ nữ. Số lượng lao động nữ di cư vào VKTTĐPN thường đông hơn nam giới, nhưng họ lại là nhóm người dễ bị tổn thương nhất. Ngoài những khó khăn mà chị em phải đối mặt như nam giới thì họ luôn phải đề phòng nạn cướp bóc, trấn lột, bạo hành, buôn bán phụ nữ, xâm hại; đặc biệt là số lao động nữ làm việc trong các nhà hàng, khách sạn, các quán karaoke, vũ trường, những tụ điểm vui chơi, giải trí là nhóm người có nguy cơ cao về các rủi ro xã hội.

\section{4. Đô thị hóa nhiều nơi còn mang tính tự phát, thiếu qui hoạch}

Sự dễ dãi, sự yếu kém trong qui hoạch, quản lý, sử dụng cùng với tư tưởng chạy theo lợi ích kinh tế trước mắt đã đưa tới tình trạng sử dụng quỹ đất tuỳ tiện, lãng phí. Hầu hết các khu công nghiệp, dịch vụ, dân cư đều bám dọc các quốc lộ huyết mạch, các vùng nông thôn trù phú. Hệ quả là, hàng chục vạn hécta đất nông nghiệp màu mỡ, nền tảng bảo đảm an ninh lương thực quốc gia đã bị sử dụng cho mục đích khác, tác động mạnh đến công ăn việc làm. Việc mở rộng đô thị thiếu kiểm soát làm mất đất nông nghiệp cùng với tác động của biến đổi khí hậu làm cho những bất cập của đô thị ngày càng trầm trọng hơn. Khó khăn chồng chất cho Tp.HCM trong giải bài toán chống ngập đô thị là một ví dụ điển hình. Vấn đề đặt ra là muốn phát triển kinh tế bền vững thì cần giải quyết được những vấn đề vừa nêu, phải phát triển đô thị theo hướng tăng trưởng xanh. Cụ thể là, dù đã chậm nhưng các địa phương nhất thiết phải quy hoạch phát triển công nghiệp, cơ sở hạ tầng, giao thông một cách hợp lý với ưu tiên hàng đầu giữ lại những mảng xanh, bảo vệ tài nguyên thiên nhiên và nguồn nước. Cũng đã đến lúc, trong sản xuất phải tính đến việc giảm tối đa sử dụng nhiên liệu để tránh ô nhiễm môi trường.

Một vấn đề nữa mà các địa phương trong VKTTĐPN phải tính đến, đó là liên kết như thế nào để tận dụng tối đa lợi thế của từng tỉnh, thành phục vụ cho sự phát triển chung. Có như thế mới nâng cao tính cạnh tranh của vùng. Từ hạ tầng sân bay, bến cảng đến dịch vụ thương mại, $\mathrm{du}$ 
lịch hay nguồn nguyên liệu nông, thủy sản...đều phải được nhìn nhận, đưa ra hướng phát triển một cách có hệ thống, tránh manh mún, nhỏ lẻ, lãng phí. Với các dự án có tính toàn vùng, nhất thiết phải có sự tham gia của cộng đồng dân cư, doanh nghiệp, các địa phương và Trung ương. VKTTĐPN là cầu nối với đồng bằng sông Cửu Long, Tây Nguyên, là nơi giao thương kinh tế quan trọng trong toàn khu vực miền Nam Việt Nam. Toàn VKTTĐPN hiện đóng góp 60\% nguồn thu ngân sách, gần $40 \%$ kim ngạch xuất khẩu của cả nước. Nhưng hiện nay, vùng kinh tế trọng điểm này cũng đang có nhiều bất cập về mạng lưới giao thông chưa đáp ứng được yêu cầu liên kết vùng, chưa có một cơ quan điều phối các chính sách liên kết. VKTTĐPN đang rất cần một cơ chế chính sách riêng cho phát triển và cần hơn nữa là một đầu mối điều phối toàn vùng. Có như thế, các địa phương trong vùng mới khắc phục được những bất cập hiện tại, kết nối với nhau chặt chẽ và phát huy được tiềm lực, hướng đến phát triển bền vững.

Tuy nhiên nhìn chung hệ thống đô thị tại VKTTĐPN đang phát triển nhanh về số lượng nhưng chất lượng cuộc sống tại các khu đô thị còn chưa cao. Đặc biệt, hệ thống hạ tầng kỹ thuật và hạ tầng xã hội chưa đồng bộ; trình độ và năng lực quản lý và phát triển đô thị còn thấp so với yêu cầu; Tốc độ xây dựng cơ sở hạ tầng ở phần lớn đô thị tại VKTTĐPN đều chậm so với phát triển kinh tế xã hội. Tình trạng phát triển đô thị hiện nay tại VKTTĐPN vẫn chưa đáp ứng với sự đổi thay về tư duy đô thị hóa, phát triển đô thị theo hướng công nghiệp hóa, hiện đại hóa, phát triển đô thị gắn với phát triển bền vững.

Phát triển đô thị và đô thị hóa trên VKTTĐPN hiện chưa thể hiện rõ bản sắc địa phương và đặc điểm khí hậu vùng, miền, tạo sự cách biệt giữa đô thị và nông thôn. Bộ mặt kiến trúc cảnh quan đô thị tại VKTTĐPN còn lộn xộn, thiếu thẩm mỹ. Tài nguyên đất bị khai thác triệt để để xây dựng đô thị, diện tích cây xanh và mặt nước bị thu hẹp, nhu cầu sản xuất, dịch vụ ngày càng tăng làm suy thoái nguồn tài nguyên thiên nhiên của đất nước. Hệ thống hạ tầng đô thị bị quá tải gây nên các hiện tượng tắc nghẽn giao thông, úng ngập và vệ sinh môi trường đô thị hóa lan rộng làm các khu vực này lại nằm lọt vào giữa khu dân cư đông đúc. Việc mở rộng đô thị dẫn đến chiếm dụng đất nông nghiệp ảnh hưởng đến an toàn lương thực quốc gia. Năng lực thu gom xử lý rác thải rắn đặc biệt là các chất thải rắn nguy hại chưa được thực hiện đúng quy định.

\subsection{Hệ thống cơ sở hạ tầng không theo kịp tốc độ đô thị hóa}

Các tuyến đường liên vùng, hướng tâm, vành đai, các tuyến nối cảng biển, cảng hàng không và cửa khẩu quốc tế của VKTTĐPN chưa hoàn chỉnh. Bên cạnh đó, mạng lưới đường sắt đầu mối chưa phát triển, chưa có đường sắt tốc độ cao; tình trạng quá tải diễn ra cả giao thông đô thị và trên một số tuyến đường bộ, cảng hàng không, cảng biển và đường thủy nội địa. Đây chính là điểm nghẽn không những cho phát triển đô thị mà còn cả phát triển kinh tế-xã hội của VKTTĐPN. Rõ ràng hệ thống cơ sở hạ tầng chưa theo kịp tốc độ phát triển của kinh tế xã hội khi mà năm 2018, tổng GRDP của VKTTĐPN đạt khoảng 2,517 triệu tỷ đồng, chiếm tỷ trọng 45,42\% GDP của cả nước. Riêng quy mô GRDP của 4 tỉnh, thành phố là TpHCM, Bình Dương, Đồng Nai và Bà RịaVũng Tàu chiếm $87,64 \%$ GRDP của VKTTĐPN. Thu ngân sách của VKTTĐPN đạt khoảng 608.000 tỷ đồng, chiếm 42,6\% tồng nguồn thu của cả nước. Tốc độ tăng trưởng GRDP bình quân hàng năm của VKTTĐPN đạt khoảng 6,72\%/năm (thời kỳ 2016-2018).

Mặc dù VKTTĐPN luôn được đánh giá là vùng động lực phát triển kinh tế-xã hội và đóng vai trò là đầu tàu, đóng góp lớn cho nền kinh tế, nhưng VKTTĐPN lại chưa được đầu tư tương xứng, đặc biệt là hạ tầng giao thông kết nối. Ví dụ, tại TpHCM thì trung bình $11 \mathrm{~km}^{2}$ diện tích mới chỉ có $2,1 \mathrm{~km}$ đường, trong khi theo chuẩn thì $1 \mathrm{~km}^{2}$ diện tích phải có $10 \mathrm{~km}$ đường. Như vậy để đạt chuẩn $10 \mathrm{~km}$ đường $/ \mathrm{km}^{2}$, nếu với tốc độ xây đường của Thành phố như vừa qua thì phải cần 50 năm nữa mới làm đủ chiều dài đường theo tiêu chuẩn. Tiếp theo, nếu cả nước có $800 \mathrm{~km}$ đường cao tốc thì khu vực VKTTĐPN chỉ có $91 \mathrm{~km}$, chiếm $11 \%$. Cơ sở hạ tầng không theo kịp sự phát 
triển của nền kinh tế cho thấy đây thực sự là một khó khăn cho sự phát triển của VKTTĐPN trong giai đoạn tới. Một vùng địa lý tạo ra hơn $42 \%$ ngân sách cho cả nước, trong khi tính tới hiện tại mới chỉ có khoảng $11 \%$ số km đường cao tốc của quốc gia, đã thấy rằng vùng chưa được đầu tư tương xứng. Đây là một bất cập đang ảnh hưởng tiêu cực không những đến đến tốc độ tăng trưởng kinh tế của VKTTĐPN sẽ giảm dần mà còn làm giảm tính hấp dẫn của Vùng trong việc thu hút nguồn vốn đầu tư từ bên ngoài. Do đó phải cần có những chính sách mạnh mẽ về quy hoạch hạ tầng giao thông tại VKTTĐPN nhằm tạo đà cho đô thị hóa đi đôi với thúc đẩy tăng trưởng kinh tế.

Đặc điểm thói quen sử dụng giao thông cá nhân gây lãng phí nghiêm trọng nguồn thiên nhiên, ô nhiễm môi trường không khí và tiếng ồn. Về kinh tế, tài chính đô thị còn hoạt động kém hiệu quả, công tác điều phối vốn đầu tư xây dựng còn bị dàn trải, việc huy động vốn từ các nguồn vốn vay, khối kinh tế tư nhân và từ cộng đồng chưa tạo động lực kích hoạt quá trình phát triển. Phát triển các khu kinh tế, đặc khu kinh tế, các khu công nghiệp tập trung cấp quốc gia, cấp tỉnh còn giàn trải chưa có sự lựa chọn thích hợp cho thành công. Đối với công tác quy hoạch, bất cập hiện nay là chưa xác định rõ mối quan hệ giữa quy hoạch sử dụng đất với quy hoạch xây dựng, quy hoạch đô thị, quy hoạch các ngành. Chưa có nhiều đồ án, dự án cải tạo, chỉnh trang đô thị được thực hiện do loại hình dự án này khá phức tạp thiếu quy định luật pháp, các nhà đầu tư chưa thực sự quan tâm.

Về quản lý đô thị còn chưa theo kịp thực tiễn, chưa đáp ứng xu thế phát triển đô thị. Đầu tư phát triển đô thị, khu dô thị mới chưa có kế hoạch nhiều nơi làm sai, chậm muộn so với quy hoạch. Chính quyền chưa có giải pháp điều hòa các lợi ích nhà nước - chủ đầu tư và người dân, công tác khớp nối hạ tầng kỹ thuật, không gian, kiến trúc đô thị chưa được thực hiện do thiếu quy chế quản lý kiến trúc cảnh quan hoặc có quy chế nhưng triển khai áp dụng còn hạn chế. Kết nối hạ tầng kỹ thuật và hạ tầng xã hội triển khai chậm, thiếu đồng bộ, công tác quản lý môi trường đô thị chưa chặt chẽ.

Tình trạng lãng phí đất đai trong các đô thị chưa được khắc phục, hiệu quả đầu tư xây dựng còn thấp ảnh hưởng đến phát triển bền vững và diện mạo đô thị. Nguồn lực cho phát triển đô thị còn dải trải. Nhu cầu vốn đầu tư cho hạ tầng kỹ thuật đô thị lớn, việc xã hội hóa, huy động các nguồn lực trong xã hội còn hạn chế. Tỷ lệ dân đô thị được cấp nước sạch còn thấp. Tình trạng úng ngập cục bộ trong mùa mưa, ô nhiễm môi trường, ách tắc giao thông, lấn chiếm đất công, xây dựng không phép, sai phép còn diễn ra ở nhiều đô thị. Xử lý nước thải chưa được chú trọng tại hầu hết các đô thị, thiếu sự đồng bộ trong xây dựng và khai thác hệ thống hạ tầng kỹ thuật dọc các tuyến đường tại các đô thị. Hệ thống cây xanh công viên ở nhiều đô thị chưa được quan tâm, thiếu quy hoạch và kế hoạch triển khai đầu tư. Hệ thống cây xanh, mặt nước (sông, hồ) trong nhiều đô thị bị suy giảm.

\section{Hàm ý chính sách}

Như vậy, cơ sở lý thuyết cũng như các nghiên cứu thực nghiệm đã khẳng định đô thị hóa có thể giúp thúc đẩy tăng trưởng kinh tế. Tuy nhiên, không thể kết luận chắc chắn rằng tỷ lệ đô thị hóa tăng lên thì tăng trưởng kinh tế sẽ mạnh mẽ hơn. Dựa trên phân tích thực trạng về đô thị hóa tại các tỉnh thành vùng VKTTĐPN, nhóm nghiên cứu đưa ra một số hàm ý chính sách nhằm gắn kết đô thị hóa với thúc đẩy tăng trưởng kinh tế tại VKTTĐPN trong thời gian tới.

Thứ nhất, các thành phố tại VKTTĐPN đóng một vai trò quan trọng trong kết cấu kinh tế và xã hội của cả nước không chỉ đóng góp vào sản lượng quốc gia, thu ngân sách mà còn thông qua việc cung cấp các cơ hội về giáo dục, việc làm và dịch vụ y tế. Do đó, các cơ quan chức năng cần thống nhất chiến lược phát triển đô thị hóa tại các địa phương thuộc VKTTĐPN nhằm giúp duy trì vai trò "đầu tàu" trong thúc đẩy tăng trưởng kinh tế quốc gia nhưng cũng có các nguồn lực cần thiết để duy trì, củng cố, phát triển các khu đô thị trên địa bàn theo hướng hiện đại. 
Thứ hai, các cơ quan chức năng cần nghiên cứu ban hành các quy chế mới nhằm quản lý phát triển các khu đô thị thuộc VKTTĐPN nhằm tập hợp các nguồn lực xã hội vào phát triển kinh tế và kéo giảm chi phí sản xuất kinh doanh. Cần các biện pháp quản lý vấn đề đô thị hóa sao cho đô thị hóa không phải là "gánh nặng" mà là quá trình tốt để giảm chi phí hoạt động, thúc đẩy chuyên môn hóa và gia tăng sự sáng tạo trong sản xuất kinh doanh. Giai đoạn sắp tới sẽ chứng kiến sự "bùng nổ" của quá trình đô thị hóa tại Việt Nam khi mà thu nhập bình quân đầu người đang gia tăng nhanh chóng và vốn đầu tư nước ngoài đang liên tục tăng lên. Do đó, cần thiết lập khuôn khổ pháp lý nhằm thúc đẩy đô thị hóa gắn kèm với tăng trưởng kinh tế mạnh mẽ hơn.

Thứ ba, trong thời gian tới nên có các giải pháp cụ thể cho việc phát triển đô thị trong quan hệ hài hòa với phát triển xã hôi. Không vì đô thị hóa mà làm giảm chất lượng cuộc sống người dân và gia tăng gánh nặng ngân sách. Cần quy hoạch các khu đô thị của VKTTĐPN trở thành các trung tâm dịch vụ, khởi nghiệp và tự kinh doanh. Người dân thành thị tiếp cận các dịch vụ hành chính công một cách nhanh chóng, dễ dàng và hiện đại. Cần xây dựng các đô thị thành các khu vực "thông minh" để thu hút sự di cư của nhân tài và những người có kỹ năng đến các thành phố lớn. Sự tập trung này gây ra sự tương tác và tạo ra sự lan tỏa kiến thức và kỹ năng. Những lao động có trình độ chuyên môn cao được tiếp xúc với những người có kỹ năng tương tự thì điều này làm tăng năng suất ở các khu vực thành thị.

Thứ tu, cần nghiên cứu các chính sách giúp gia tăng tác động lan tỏa hoặc ngoại ứng tích cực của phát triển đô thị đối với khu vực nông thôn tại các địa phương trong VKTTĐPN. Thông qua di cư, kiều hối và các hoạt động tương tác giữa thành thị và nông thôn, đô thị hóa có thể có những tác động tích cực đến cả tài chính và vốn con người. Thông qua di cư, chuyển giao thông tin, kỹ năng sản xuất và công nghệ đều có thể được cải thiện ở các khu vực đưa người di cư đến. Đô thị hóa nhanh chóng có thể tác động tiêu cực đến nền kinh tế thông qua tác động làm tắt nghẽn, xuống cấp hệ thống cơ sở hạ tầng. Cần phân tích, nghiên cứu sự tác động của đô thị hóa đến tăng trưởng kinh tế là hoạt động mang tính phức tạp và phụ thuộc vào một số yếu tố như trình độ phát triển, giai đoạn đô thị hóa và bản chất của các hoạt động kinh tế xã hội chủ đạo trên địa bàn

\section{LÒ̀I CẢM ƠN}

Nghiên cứu này được tài trợ bởi Quỹ Phát triển khoa học và công nghệ Quốc gia (NAFOSTED) trong đề tài mã số 502.01-2019.04

\section{Tài liệu tham khảo}

Barrios, S., Luisito, B., \& Strobl, E. (2006). Climate change and rural-urban migration: The case of sub-saharan Africa. Journal of Urban Economics, 60(3), 357-71.

Bộ Kế hoạch và Đầu tư. (2019). Xu hương đô thị hóa tại Việt Nam giai đoạn 2021-2030 và một số hẹ luy [Urbanization trend in Vietnam in the period of 2021-2030 and its implications]. Retrieved May 6, 2019, from http://ncif.gov.vn/Pages/NewsDetail.aspx?newid=21873

Burgess, R., \& Venables, A. J. (2003). Towards a microeconomics of growth (World Bank Working Paper 3257). Retrieved May 5, 2019, from https://www.lse.ac.uk/economics/Assets/Documents/personal-pages/robinburgess/microeconomics-of-growth.pdf

Collier, P. (2006). Africa: Geography and growth. Retrieved May 7, 2019, from http://purocihle.rrojasdatabank.info/NEG17Collier.pdf

Dorosh, P., \& James T. (2012). Agglomeration, growth and regional equity: An analysis of agriculture- versus urban-led development in Uganda. Journal of African Economies, 21(1), 94-123. 
Greenstone, M., Hornbeck, R., \& Moretti, E. (2007). Identifying agglomeration spillovers: Evidence from million dollar plants (NBER Working Paper 13833). Retrieved May 9, 2019, from https://www.nber.org/papers/w13833

Henderson, J. V. (2010). Cities and development. Journal of Regional Science, 50(1), 515-540.

Landes, D. S. (1969). The unbound Prometheus. Cambridge, UK: Cambridge University Press.

Lewis, W. A. (1977). The evolution of the international economic order. Retrieved May 11, 2019, from Oxford Academic website: https://academic.oup.com/ahr/articleabstract/84/1/106/63480?redirectedFrom=fulltext

Liddle, B. (2013). Urban density and climate change: A STIRPAT analysis using city-level data. Journal of Transport Geography, 28, 22-29.

Liddle, B., \& Messinis, G. (2015). Which comes first-urbanization or economic growth? Evidence from heterogeneous panel causality tests. Appl. Econ. Lett, 22, 349-355.

Loughran, T., \& Schultz, P. (2005). Liquidity: Urban versus rural firms. Journal of Financial Economics, 78, 341-374.

Lucas, R. E. (1988). On the mechanics of economic development. Journal of Monetary Economics, 22(1), 3-42.

Lucas, R. E. (2004). Life earnings and rural-urban migration. Journal of Political Economy, 112(1), S29-S59.

Lucas, R. E. (2007). Trade and the diffusion of the industrial revolution (NBER Working Paper 13286). Retrieved May 10, 2019, from https://www.nber.org/papers/w13286

Rosenthal, S., \& William C. S. (2004). Evidence on the nature and sources of agglomeration economies. In J. V. Henderson \& J. F. Thisse, Handbook of Regional and Urban Economics, (4th ed.). Amsterdam, Netherlands: Elsevier.

Satterthwaite, D. (2007). The transition to a predominantly urban world and its underpinnings. Retrieved May 11, 2019, from https://pubs.iied.org/sites/default/files/pdfs/migrate/10550IIED.pdf

Tổng cục thống kê. (2020). Niên giám thống kê 2019 [Statistical Yearbook 2019]. Hanoi, Việt Nam: Nhà xuất bản Thống kê.

Tổng cục thống kê. (2021). Co sở dĩu liệu [Database]. Retrieved May 12, 2019, from https://www.gso.gov.vn/

Williamson, J. G. (1987). Did England's cities grow too fast during the industrial revolution? (Discussion Paper 1311). Cambridge, MA: Harvard Institute of Economic Research.

Williamson, J. G. (1990). Coping with city growth during the British industrial revolution. Cambridge, UK: Cambridge University Press. 